\title{
Studies on the effects of chemical preservatives on the quality of strawberry (Fragaria ananassa) juice in Bangladesh
}

\author{
Sabina $\mathrm{R}^{1}$, Miyan $\mathrm{SH}^{2}$, Hoque $\mathrm{MM}^{1}$ * \\ Department of Food Engineering and Tea Technology ${ }^{1}$, Department of Genetic Engineering and \\ Biotechnology', ShahJalal University of Science and Technology, Sylhet Bangladesh.
}

[Received: November 29, Accepted: December 25, 2011]

\begin{abstract}
This study was carried out to assess the nutritive value of fresh strawberry (Fragaria ananassa) juice and to observe the effect of chemical preservatives on the acidity, ascorbic acid and total soluble solids (TSS) content of strawberry juice. Strawberry was being collected from the local farm of Sylhet city. The proximate composition of strawberry juice was found to have contents of moisture $89.64 \%$, fat $0.48 \%$, fiber $1.013 \%$, ash $0.53 \%$, Titrable acidity $1.02 \%$, ascorbic acid $120 \mathrm{mg} / 100 \mathrm{~g}$, TSS $6 \%$, and $\mathrm{pH} \quad 3.7$. To observe the effects of chemical preservatives the samples were treated with $30 \%$ sucrose, $0.2 \%$ sodium benzoate, $0.2 \%$ potassium sorbet, mixture of $30 \%$ sucrose and $0.2 \%$ sodium benzoate, mixture of $30 \%$ sucrose and $0.2 \%$ potassium sorbet, mixture of $30 \%$ sucrose, $0.2 \%$ sodium benzoate and $0.2 \%$ potassium sorbet. The study was conducted for 3 months; storage on refrigeration temperature and the content of acidity; ascorbic acid and TSS were assessing every $15^{\text {th }}$ day's interval. The result showed mixture of $30 \%$ sucrose, $0.2 \%$ sodium benzoate and $0.2 \%$ potassium sorbet gives retention to most of the nutrients during 3 months storage. The results showed that the ascorbic acid of the juice was found to be with minimum percentage decrease in sample $\mathrm{T}_{6}(6.93 \%)$ and maximum in $\mathrm{T}_{0}(64.69)$, on acidity of juice there was no such significant changes thus showing similar mean values in the samples, and TSS of juice recorded maximum mean value in $\mathrm{T}_{6}(33.5)$ and minimum mean value $\mathrm{T}_{0}$ (5.1) where maximum increase was observed in $\mathrm{T}_{0}(20 \%)$ and minimum in $\mathrm{T}_{5}(3.54)$. The results suggested that the effects of chemical preservatives have significant role in strawberry juice and its livelihood. The changes of ascorbic acid content of strawberry juice for $\mathrm{T}_{0}$ treatment significantly changes with $T_{3}(p=.025), T_{4}(p=.029), T_{5}(p=.027), T_{6}(p=.001)$. The changes of acidity treated with different preservatives significantly changes with period of time but insignificantly changes with the treatment. The changes of TSS content of strawberry juice significantly changes with treatment. The homogeneous subsets are $T_{0} T_{2} T_{4}$ and the subsets $b$ contain $T_{3}, T_{1}, T_{5}$ and $T_{6}$ $(\mathrm{p}=0.000)$. Among all the treatments $\mathrm{T}_{6}$ were most effective in maintaining the nutritional quality during storage.
\end{abstract}

Keyword: strawberry, juice, acidity, ascorbic acid.

\section{INTRODUCTION}

Strawberry (Fragaria ananassa) has delicious flavor, attractive color, shape and structure that are why the demand of this fruit is increasing day by day in Bangladesh. Strawberry is a herbaceous, perennial member of the family "Rosaceae", which is grown in many countries of the world ${ }^{[1,2]}$. It has been commercially cultivated in Canada, USA, Japan, Spain, Germany, Korea, Italy, Poland, Thailand and many other countries in the world ${ }^{[3]}$. To reduces the deterioration rate in the transporting time the fruits should be handled carefully, because there are high chances of deterioration of fruit during transportation. Fresh fruit is mainly consumed and it also used processed form such as cooked and sweetened preserves that is jams or jellies and frozen whole berries ${ }^{[4]}$. The fruit is firm, red fleshed and sweet. More than $50 \%$ of the sucrose in strawberries is glucose. The fruit contains mainly citric acid and some malic acid. The red color of the fruit is due to anthocyanin pigment. The flavor of the fruit present in it is due to present of many Volatile esters ${ }^{[4]}$. Strawberries vary in level and types of acids they contain. For example, a study of "Camarosa" and "Selva" strawberries showed citric acid, malice acid and ascorbic acid contents as $0.76 \%, 0.13 \%, 0.04 \%$ and $0.5 \%, 0.0 \%$ and $0.04 \%$ respectively ${ }^{[5]}$. Sodium benzoate used in fruit juices as an antimicrobial agent at concentrations of 0.05 to $0.1 \%$. It is ineffective at $\mathrm{pH}$ values near neutrality and the effectiveness increases with increase in acidity. It is most effective in the $\mathrm{pH}$ ranges of 2.5 to $4^{[6]}$. Due to lack of other preservation facilities to preserve the product in raw form, this study has been initiated to utilize the very perishable fruit in the form of juice and to study the affect of chemical preservatives on the preservation quality of strawberry juice, at refrigeration storage ${ }^{[7]}$. It is hoped that the findings will help the beverage industries to utilize this fruit for juice preparation with increased shelf life stability and consumer demand.

\section{MATERIALS AND METHODS}

Collection of Samples: Fresh mature and sound strawberries (Fragaria ananassa) were collected from the local farm of Sylhet, Tukerbazar and the experiment was carried out with the collaboration of the department of Food Engineering and Tea Technology and Chemical Engineering laboratory, Shahjalal University of Science and Technology, Sylhet, Bangladesh. Collected $5 \mathrm{~kg}$ fresh strawberry fruits were used to make juice sample. 
Table 2: Effect of treatments and storage on ascorbic acid (mg/100g) of strawberry juice:

$$
\text { Interval (days) }
$$

\begin{tabular}{|c|c|c|c|c|c|c|c|c|c|}
\hline Treatments & $1^{\mathrm{st}}$ & $15^{\text {th }}$ & $30^{\text {th }}$ & $45^{\text {th }}$ & $60^{\text {th }}$ & $75^{\text {th }}$ & $90^{\text {th }}$ & $\begin{array}{l}\text { Mean } \\
\pm \mathrm{SD}\end{array}$ & \%decrease \\
\hline $\mathrm{T}_{0}$ & 49 & 45.1 & 39.6 & 33.5 & 27.5 & 23.5 & 17.3 & $\begin{array}{l}33.64^{\mathrm{a}} \\
\pm 11.62\end{array}$ & 64.69 \\
\hline $\mathrm{T}_{1}$ & 47.8 & 45.3 & 43.4 & 41.2 & 39.1 & 37.0 & 34.8 & $\begin{array}{l}41.22^{\mathrm{ab}} \\
\pm 4.62\end{array}$ & 27.2 \\
\hline $\mathrm{T}_{2}$ & 48 & 45.1 & 43.8 & 42.5 & 40.4 & 38.2 & 33.2 & $\begin{array}{l}41.6^{\mathrm{ab}} \\
\pm 4.87\end{array}$ & 30.8 \\
\hline $\mathrm{T}_{3}$ & 47.9 & 45.5 & 44.4 & 43.2 & 42.2 & 41.1 & 40.1 & $\begin{array}{l}43.48^{\mathrm{b}} \\
\pm 2.68\end{array}$ & 16.28 \\
\hline $\mathrm{T}_{4}$ & 47.5 & 47.1 & 45.4 & 43.1 & 41.1 & 39.7 & 39.5 & $\begin{array}{r}43.34^{\mathrm{b}} \\
\pm 3.38\end{array}$ & 16.84 \\
\hline $\mathrm{T}_{5}$ & 48 & 47.1 & 44.4 & 41.3 & 41.1 & 41 & 41 & $\begin{array}{l}43.41^{\mathrm{b}} \\
\pm 3.08\end{array}$ & 14.58 \\
\hline $\mathrm{T}_{6}$ & 49 & 47.8 & 47.5 & 46.9 & 46.9 & 45.7 & 45.6 & $\begin{array}{l}47.05^{\mathrm{b}} \\
\pm 1.19\end{array}$ & 6.93 \\
\hline
\end{tabular}

Means

\begin{tabular}{llllllll} 
& $48.1^{\mathrm{c}}$ & $46.14^{\mathrm{bc}}$ & $44.07^{\mathrm{abc}}$ & $41.60^{\mathrm{abc}}$ & $39.75^{\mathrm{abc}}$ & $38.02^{\mathrm{ab}}$ & $35.9^{\mathrm{a}}$ \\
$\pm \mathrm{SD}$ & \pm 0.59 & \pm 1.14 & \pm 2.38 & \pm 4.07 & \pm 5.93 & \pm 6.97 & \pm 9.17 \\
\hline
\end{tabular}

The same letter indicated that the mean different is not significantly affected $(\mathrm{P}<0.05)$. In these data a, b, ab, bc, abc, cd, de, e significantly differ from each other.

Then sample was divided into two parts. One pasteurized and another non-pasteurized. The non pasteurized juice was used to analysis of $\mathrm{pH}$, vitamin juice, TSS (total soluble solid), fat, fiber, moisture etc. and another pasteurized part is divided into 7 parts in which preservatives $(30 \%$ sucrose, $0.2 \%$ 


\begin{tabular}{|c|c|c|c|c|c|c|c|c|c|}
\hline & & & Interva & (days) & & & & & \\
\hline Treatments & $1^{\text {st }}$ & $15^{\text {th }}$ & $30^{\text {th }}$ & $45^{\text {th }}$ & $60^{\text {th }}$ & $75^{\text {th }}$ & $90^{\text {th }}$ & Means & \%Increase \\
\hline $\mathrm{T}_{0}$ & 1.40 & 1.60 & 1.80 & 2.00 & 2.30 & 2.60 & 2.90 & $\begin{array}{l}2.08^{\mathrm{a}} \\
\pm 0.54\end{array}$ & 107.14 \\
\hline $\mathrm{T}_{1}$ & 1.43 & 1.63 & 1.83 & 2.10 & 2.30 & 2.60 & 2.85 & $\begin{array}{l}2.10^{\mathrm{a}} \\
\pm 0.51\end{array}$ & 99.30 \\
\hline $\mathrm{T}_{2}$ & 1.34 & 1.30 & 1.50 & 1.70 & 2.00 & 2.20 & 2.30 & $\begin{array}{l}1.76^{\mathrm{a}} \\
\pm 0.40\end{array}$ & 71.6 \\
\hline $\mathrm{T}_{3}$ & 1.43 & 1.63 & 1.83 & 2.13 & 2.33 & 2.63 & 2.90 & $\begin{array}{l}2.13^{\mathrm{a}} \\
\pm 0.53\end{array}$ & 102.8 \\
\hline $\mathrm{T}_{4}$ & 1.35 & 1.34 & 1.54 & 1.74 & 1.94 & 2.24 & 2.13 & $\begin{array}{l}1.75^{\mathrm{a}} \\
\pm 0.36\end{array}$ & 73.3 \\
\hline $\mathrm{T}_{5}$ & 1.42 & 1.44 & 1.48 & 1.51 & 1.71 & 2.01 & 2.31 & $\begin{array}{l}1.69 \mathrm{a} \\
\pm 0.34\end{array}$ & 62.7 \\
\hline $\mathrm{T}_{6}$ & 1.40 & 1.21 & 1.31 & 1.51 & 1.71 & 1.90 & 2.13 & $\begin{array}{l}1.59 \mathrm{a} \\
\pm 0.33\end{array}$ & 51.1 \\
\hline Means & $\begin{array}{l}1.39^{\mathrm{s}} \\
\pm \\
0.03\end{array}$ & $\begin{array}{l}1.45^{\mathrm{ab}} \\
\pm 0.17\end{array}$ & $\begin{array}{l}1.61^{\mathrm{ab}} \\
\pm 0.20\end{array}$ & $\begin{array}{l}1.81^{b c} \\
\pm 0.26\end{array}$ & $\begin{array}{l}2.04^{c d} \\
\pm 0.27\end{array}$ & $\begin{array}{l}2.31 \text { de } \\
\pm 0.30\end{array}$ & $\begin{array}{l}2.50^{\mathrm{e}} \\
\pm 0.36\end{array}$ & & \\
\hline
\end{tabular}

The same letter indicated that the mean different is not significantly affected $(\mathrm{P}<0.05)$. In these data $\mathrm{a}, \mathrm{ab}, \mathrm{bc}, \mathrm{cd}$, de, e significantly differ from each other If $\mathrm{p}$ value is less than 0.05 than it means it is significant.

sodium benzoate, $0.2 \%$ potassium sorbet, mixture of $30 \%$ sucrose and $0.2 \%$ sodium benzoate, mixture of $30 \%$ sucrose and $0.2 \%$ potassium sorbet, mixture of $30 \%$ sucrose, $0.2 \%$ sodium benzoate and $0.2 \%$ potassium sorbet) ${ }^{[1]}$ were added in each samples in given amount and observed the effects of chemical preservatives on Acidity, Vitamin C and TSS content during the storage of juice on 3 months duration ${ }^{[1,8]}$. The research work was carried out to assess the nutritive value of strawberry juice and to observe the effect of chemical preservatives on the $\mathrm{pH}$, acidity, ascorbic acid (vitamin C), total soluble solids (TSS) of the strawberry juice on 3 months storage on refrigeration temperature ${ }^{[8,9]}$. The samples were totally fresh and free from any type of injury or deterioration.

\section{Treatments of samples:}

$\mathrm{T}_{0=}$ Pasteurized juice of strawberry juice

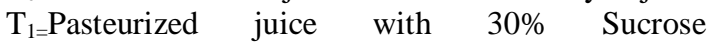
$\mathrm{T}_{2=}$ Pasteurized juice with $0.2 \%$ Sodium benzoate $\mathrm{T}_{3}=$ Pasteurized juice with $30 \%$ Sucrose and $0.2 \%$ sodium benzoate

$\mathrm{T}_{4}=$ Pasteurized juice with $0.2 \%$ potassium sorbet $\mathrm{T}_{5=}$ Pasteurized juice with $30 \%$ sucrose and $.2 \%$ potassium-sorbet

$\mathrm{T}_{6=}$ Pasteurized juice with $30 \%$ sucrose and $.2 \%$ sodium benzoate and $0.2 \%$ potassium sorbet. The berries were washed followed by sorting, the juice was extracted using juice extracting machine.

Sample of preservatives: (1) $30 \%$ sucrose (2) $0.2 \%$ sodium benzoate (3) $0.2 \%$ potassium sorbet (4) $30 \%$ sucrose $+0.2 \%$ sodium benzoate (5) $30 \%$ sucrose + $0.2 \%$ potassium sorbet (6) $30 \%$ sucrose $+0.2 \%$ sodium benzoate $+0.2 \%$ potassium sorbet.
Chemical analysis: Reducing and non-reducing sucrose was determined by lane Eynon method ${ }^{[10]}$.The Determination of Titrable Acidity was followed by the methodology of AOAC [11] and determination of vitamic $\mathrm{C}$ and organic acid changes were followed by the methodology of Koyuncu MA and Dilmacunal $\mathrm{T}^{[12]}$. Acidity was determined by dissolving a known weight of sample in distilled water and titration against $0.01 \mathrm{~N} \mathrm{NaOH}$ using phenolphthalein as indicator ${ }^{[13]}$. Inolab digital $\mathrm{pH}$ meter was used for $\mathrm{pH}$ determination. Reducing and non-reducing sucrose was determined by lane Eynon method ${ }^{[10]}$. The total soluble solids (TSS) were determined by using Abbe refractometer at room ${ }^{[10]}$.

The Statistical Analysis: All the statistical analysis was carried out using SYSTAT 5 (systac Inc., 1992). ANOVA $(\mathrm{p}<0.05)$ was carried out to determine the significance in the effects of acidity, ascorbic acid and TSS.

\section{RESULTS AND DISCUSSION}

The Proximate composition of strawberry juice is given in Table 1: below. In this study the vitamin $\mathrm{C}$ contents of $100 \mathrm{~g}$ juice is $82.33 \mathrm{mg}$. Ayub ${ }^{[1]}$ reported the vitamin $\mathrm{C}$ content $64 \mathrm{mg}$ per $100 \mathrm{~g}$. According to USDA $^{[14]}$ nutrient data base the vitamin $C$ content of strawberry $132 \mathrm{mg}$ per $100 \mathrm{~g}$. On this study, the fiber content of strawberry juice was found to be $1.23 \%$ where Ayub ${ }^{[1]}$ mentioned $2.3 \%$. The fruits contain mainly citric and malic acid. In this study the acidity contents of strawberry juice $1.05 \%$ where Ayub ${ }^{[1]}$ mentioned $0.58-1.35 \%$. The result of TSS content in the study is found to be $6.3 \%$ which is very much 
close to the result of Ayub ${ }^{[1]}$ who mentioned the TSS from $8 \%$ to $11.5 \%$. Every strawberry differs from other strawberries in nutritional point of view because of soil quality, climate and other environmental factors but the ranges of nutritional contents are very much close.

Effect of chemical preservatives on ascorbic acid of strawberry juice: Our results indicated that storage period and temperature $\left(4-16^{\circ} \mathrm{C}\right)$ had significant effect on ascorbic acid content of different samples. There was a gradual decrease in ascorbic acid of strawberry juice from $48.1 \mathrm{mg}$ initially to $35.9 \mathrm{mg}$. Results showed that minimum percent decrease in ascorbic acid content was recorded in sample $\mathrm{T}_{6}(6.93 \%)$ and maximum $\mathrm{T}_{0}$ $(64.69 \%)$ as in Table 2: below. The results are in agreement with the finding of Ayub ${ }^{[1]}$. Similar results were recorded by Nunes ${ }^{[15]}$ who recorded a change in Chandler variety of strawberries stored at $4^{0} \mathrm{C}$.

Effect of chemical preservatives on acidity of the strawberry juice: Acidity of samples $\left(T_{0}\right.$ to $\left.T_{6}\right)$ ranged from 1.34 to 1.43 . The mean values increased from 1.39 to 2.50. Maximum mean values were recorded in sample $\mathrm{T}_{3}$ (2.13), while minimum mean values were observed in sample $\mathrm{T}_{6}$ (1.59). During storage maximum increase was observed in sample $\mathrm{T}_{0}(107.14 \%)$, while minimum increase was observed in $\mathrm{T}_{6}(51.1 \%)$ as in Table 3: below. The results are confirmed by the finding of Ayub ${ }^{[1]}$. The results are also confirmed by the finding of Riaz ${ }^{[6]}$.

Effect of chemical preservatives on TSS of strawberry juice: The analysis of our data showed that different treatments and storage intervals had a significant effect on TSS of strawberry juice. Maximum mean values were recorded in $\mathrm{T}_{6}(33.5)$ and minimum mean value $\mathrm{T}_{0}$ (5.1). Maximum increase was observed in $\mathrm{T}_{0}(20 \%)$ and minimum in $\mathrm{T}_{5}$ (3.54) as in Table 4: below. These results are in agreement with Ruiz - Nieto ${ }^{[5]}$, who showed an increase in glucose and fructose contents in Strawberry juice. Similar results were recorded by Ayub ${ }^{[1]}$. who reported that TSS in fruit juices increases.

\section{CONCLUSION}

In this study results indicate that storage period and temperature $\left(4-16^{\circ} \mathrm{C}\right)$ had significant effect on ascorbic acid content of different samples. There was a gradual decrease in ascorbic acid of strawberry juice. Acidity of samples ( $\mathrm{T}_{0}$ to $\mathrm{T}_{6}$ ) ranged from 1.34 to 1.43 . The mean values increased from 1.39 to 2.50. Among all the treatments $\mathrm{T}_{6}$ were most effective in maintaining the nutritional quality during storage. Hence the effects of chemical preservatives in the TSS, ascorbic acid and acidity of the strawberry juice were found a significant result. The geographical locations, altitude and climatic condition may contribute the preservative quality of the strawberry juice in Bangladesh. This result is beneficial for further research on the strawberry juice preservation and its functionality as a good economic value.

\section{REFERENCES}

1. Muhammad Ayub, Javid Ullah, Ali Muhammad and Alam Zeb (2010). Evaluation of strawberry juice preserved with chemical preservatives at refrigeration temperature. International Journal of Nutrition and Metabolism. Vol. 2 (2) pp. 027032 .

2. Amin NU (1996). Evaluation of different strawberry cultivars for off Season production under plastic tunnel. P.I. M.Sc. (Hons) thesis, Department of Horticulture NWFP Agricultural University. Peshawar, Pakistan.

3. Galletta GJ (1997). Small Fruit Breeding for the southern United States: Strawberries. Fruit Varieties J., 51(3): 138-143. Kinh Shearer AEH, Dunne CP, Hoover DG (2001). Preparation and preservation of apple pulp with chemical preservatives and mild heat. J. Food Prot. 28(6): 111-114.

4. Nunes MCN, Morais MB, Brecht JK and Sargent SA (1995). Quality of strawberries after storage in controlled atmospheres at above optimum storage temperatures. Proceedings of the Florida State Horticultural Society. Pub. 108: 273-278.

5. Ruiz-Nieto A, Lopez AJM, Lopez MR, Lopez MJ, Medina JJ, Scheer HAT, Lieten F and Dijkstra J (1997). Analysis of sucrose's from strawberry cultivars of commercial interestcontents evolution. Proceedings of the third international strawberry symposium, Veldhoven, Netherlands, 29 Vol. 2. Acta Hor, 439:663-667.

6. Riaz RA, Ali A and Saleem M (1988). Studies on the preparation and storage stability of comminuted kinow fruit beverage bees. Pak. J.Sci. Ind. Res., 32(8): 574-578.

7. Childer NF (1980). The strawberry cultivars to marketing. Gainesbile, Fla. Falta o número das páginas. Hort. Pub. P. IX.

8. Reber JD, Eggett DL and Parker TL (2011). Antioxidant capacity interactions and a chemical/structural model of phenolic compounds found in strawberries. Int J Food Sci Nutr. 30(6): 445-452.

9. Olsson ME, Andersson CS, Oredsson S, Berglund RH and Gustavsson KE (2006). Antioxidant Levels and Inhibition of Cancer Cell Proliferation in Vitro by Extracts from Organically and Conventionally Cultivated Strawberries. Journal of Agricultural and Food Chemistry, 54(4), 124855. 
10.AOAC (1984). Official methods of Analysis. Association of Official Analytical Chemists, Washington D.C, USA. 15th ed. pp: 1058-1059.

11.AOAC (1975). Official methods of Analysis. Association of Official Analytical Chemists, Washington D.C, USA.

12. Mehmet Ali Koyuncu and Tuba Dilmacunal (2010). Determination of Vitamin C and Organic Acid Changes in Strawberry by HPLC During Cold Storage. Not. Bot. Hort. Agrobot. Cluj, 38 (3), 95-98.

13. Srivastava RP and Sanjeev K (2003). Fruit and vegetable preservation principles and practices:
Important methods for analysis of Fruits? Vegetables and their products. Third Revised and Enlarge Edition. International Book Distribution Co., Lucknow, India :363.

14.U.S Dept. of Agriculture USDA (1998). Nutrient database for standard reference, (www Oregonstrawberries.Org).

15. Nunes MCN, Morais MB, Brecht JK and Sargent SA (1995). Quality of strawberries after storage in controlled atmospheres at above optimum storage temperatures. Proceedings of the Florida State Horticultural Society. Pub. 108: 273-278. 